\title{
KOMBINASI PEMBERIAN PROGRESSIVE RESISTANCE EXERCISE DAN ISOMETRIC EXERCISE TERHADAP TINGKAT PENURUNAN NYERI LUTUT PADA KASUS OSTEOARTHRITIS
}

\author{
Arin Zakyatur Risqi*, Nungki Marlian Yuliadarwati, Safun Rahmanto \\ Departement Fisioterapi, Universitas Muhammadiyah Malang, Jalan Bandung No. 1Malang 65133 \\ *Corresponding author: risqiarin@gmail.com
}

\begin{abstract}
ABSTRAK
Osteoarthritis merupakan penyakit degeneratif pada tulang yang ditandai dengan adanya pengeroposan tulang rawan secara bertahap. Osteoarthritis dapat menimbulkan berbagai gangguan diantaranya adalah penurunan ROM, penurunan kekuatan otot, penurunan fungsi, penurunan aktifitas fungsional dan nyeri. Latihan dapat dengan pemberian kombinasi progressive resistance exercise dan isometric exercise untuk menurunkan nyeri lutut pada kasus osteoarthritis. Tujuan penelitian ini untuk mengetahui pengaruh dari pemberian kombinasi progressive resistance exercise dan isometric exercise terhadap tingkat penurunan nyeri pada kasus osteoarthritis. Subjek penelitian ini adalah warga RW 02 Kelurahan Triwung Lor Kota Probolinggo yang mengalami nyeri lutut akibat osteoarthritis dengan jumlah 19 orang. Desain penelitian ini menggunakan pre - eksperimental with one group pretest - posttest design. Alat untuk mengukur nyeri yaitu NRS (Numeric Rating Scale). Hasil penelitian membuktikan adanya pengaruh yang signifikan sebelum dan sesudah diberikan kombinasi progressive resistance exercise dan isometric exercise terhadap penurunan nyeri lutut pada kasus osteoarthritis dengan $\mathrm{p}=0,000(\mathrm{p}<0,005)$. Terdapat penurunan nyeri setelah diberikan kombinasi progressive resistance exercise dan isometric exercise pada penderita osteoarthritis di RW 02 Kelurahan Triwung Lor Kota Probolinggo.
\end{abstract}

Keywords: Lansia, Progressive Resistance Exercise, Isometric Exercise, Osteoarthritis, Nyeri

\section{PENDAHULUAN}

Seiring bertambahnya usia, seseorang akan mengalami fase penuaan dimana terdapat penurunan fungsi organ dan penurunan perkembangan fisik yangg menyebabkan timbulnya beberapa permasalahan kesehatan. Salah satu gangguan yang banyak ditemukan pada lansia adalah osteoarthritis. Osteoarthritis merupakan penyakit degeneratif pada tulang yang ditandai dengan adanya pengeroposan tulang rawan secara bertahap. Menurut Zhang \& Jordan (2010) faktor usia (degenerasi), jenis kelamin, kelebihan berat badan dan obesitas , cidera lutut, penggunaan sendi yang berulang, kepadatan tulang, kelemahan otot, dan kelemahan sendi semuanya berperan dalam perkembangan osteoarthritis sendi.

Adanya aktivitas fibrinogenik yang meningkat dan aktivitas fibrinolitik yang mengalami penurunan pada kartilago penderita osteoarthritis sehingga terjadi penumpukan trombus dan komplek lipid yang berada pada pembuluh darah subkondral. Reaksi ini akan berdampak terhadap sensasi nyeri yang dapat timbul 
akibat pelepasan mediator kimiawi seperti prostaglandin dan interleukin. Selain itu, adanya penumpukan osteofit di kartilago dan penurunan fleksibiltas pada sendi akan menyebabkan keterbatasan lingkup gerak sendi. Cairan synovial berguna sebagai minyak yang berada di sendi juga mengalami penipisan sehingga menimbulkan inflamasi kronik yang terdapat di sendi dan dapat menyebabkan adanya nyeri (Price,dkk., 2006 dalam Made,dkk, 2017).

The Osteoarthritis Research Society International (OARSI) lembaga internasional yang melakukan riset tentang osteoarthritis merekomendasikan berbagai metode non farmakologi untuk mengurangi nyeri yang diakibatkan oleh osteoarthritis diantaranya adalah program edukasi, pengurangan berat badan, dan latihan- latihan fisik (Richmond,dkk., 2010). Latihan-latihan fisik yang dapat diberikan yaitu Progressive Resistance Exercise dan Isometric Exercise.

Progressive Resistance Exercise merupakan latihan secara bertahap dimana beban dalam setiap latihan bertambah secara perlahan. Peningkatan beban secara perlahan untuk setiap latihan memungkinkan adaptasi otot yang berkelanjutan dari waktu ke waktu (Vincent, 2013). Isometric exercise dapat memberikan efek berupa penambahan ketegangan otot sedangkan panjang otot tetap tidak mengalami perubahan (Kisner\&Colby, 2012). Pemberian kombinasi progressive resistance exercise dan isometric exercise pada penderita osteoarthritis dapat meningkatkan kekuatan otot secara signifikan, peningkatan serabut otot lurik, dan kenaikan jumlah motor unit.

\section{METODE}

Penelitian ini menggunakan desain penelitian pre-eksperimental with one group pretest-posttest design, dimana peneliti menggunakan satu kelompok untuk membandingkan nyeri lutut yang dirasakan sebelum dan sesudah diberikannya kombinasi progressive resistance exercise dan isometric exercise. Sampel dipilih dengan tekhnik non probability sampling. Sampel yang telah memenuhi kriteria berjumlah 19 orang, dengan instrumen penelitian menggunakan Numeric Rating Scale (NRS) sebagai pengukuran nyeri. Uji hipotesa yang digunakan adalah uji Wilcoxon.

\section{HASIL PENELITIAN}

1. Karakteristik Responden Berdasarkan Usia

Data karakteristik responden berdasarkan usia dapat dilihat pada diagram sebagai berikut:

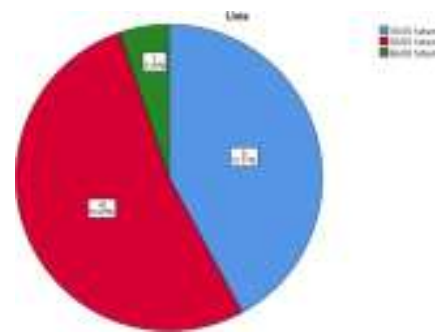

Diagram 1. Karakteristik Responden Berdasarkan Usia (Data Primer, 2020)

Berdasarkan diagram diatas didapatkan data usia yaitu responden yang berumur 46-55 tahun sebanyak 8 orang $(42,11 \%)$, 56-65 tahun sebanyak 10 orang $(52,63 \%), 66-90$ tahun sebanyak 1 orang $(5,26 \%)$. Diketahui bahwa usia responden yang banyak mengalami nyeri akibat osteoarthritis adalah 56-65 tahun. Total keseluruhan dari data berjumlah 19 responden (100,0\%). Dari hasil penelitian maka dapat disimpulkan bahwa semakin bertambahnya usia resiko terjadinya nyeri lutut akibat osteoarthritis juga semakin besar.

2. Karakteristik Responden Berdasarkan Jenis Kelamin

Data karakteristik responden berdasarkan jenis kelamin dapat dilihat pada diagram sebagai berikut: 


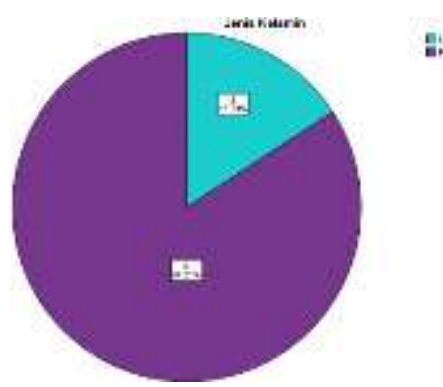

Diagram 2. Karakteristik Responden Berdasarkan Jenis Kelamin

(Data Primer, 2020)

Berdasarkan diagram diatas didapatkan distribusi responden berdasarkan jenis kelamin yaitu perempuan sebanyak 16 orang $(84,21 \%)$ dan laki-laki sebanyak 3 orang $(15,79 \%)$. Dari diagram tersebut, dapat disimpulkan bahwa perempuan lebih beresiko mengalami nyeri akibat osteoarthritis.

3. Karakteristik Responden Berdasarkan Pekerjaan

Data karakteristik responden berdasarkan pekerjaan dapat dilihat pada diagram sebagai berikut:

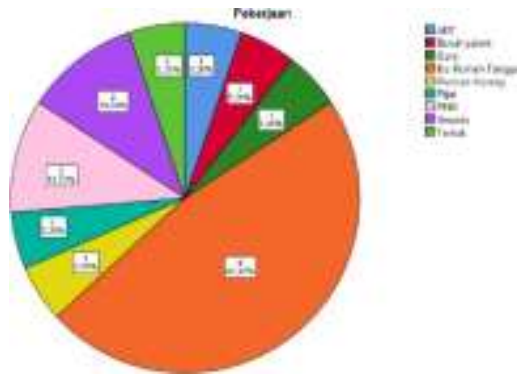

Diagram 3. Karakteristik Responden Berdasarkan Pekerjaan (Data Primer, 2020)

Berdasarkan diagram diatas didapatkan karakteristik responden bekerja dan tidak bekerja. Sebanyak 9 orang responden $(47,37 \%)$ adalah ibu rumah tangga atau tidak bekerja. Sedangkan responden yang bekerja sebanyak 10 orang $(52,63 \%)$ dengan rincian 1 orang $(5,26 \%)$ bekerja sebagai ART, 1 orang $(5,26 \%)$ bekerja sebagai buruh pabrik, 1 orang $(5,26 \%)$ bekerja sebagai guru, 1 orang $(5,26 \%)$ bekerja sebagai pencari kerang, 1 orang $(5,26 \%)$ bekerja sebagai peternak, 1 orang $(5,26 \%)$ bekerja sebagai buruh pijat, 2 orang $(10,53 \%)$ bekerja sebagai buruh swasta, dan 2 orang $(10,53 \%)$ bekerja sebagai PNS. Dari data tersebut dapat disimpulkan bahwa orang yang bekerja lebih beresiko mengalami nyeri akibat osteoarthritis. Terdapat hubungan signifikan antara pekerjaan dengan kekuatan lutut dan kejadian osteoarthritis.

4. Karakteristik Responden Berdasarkan Indeks Massa Tubuh

Data karakteristik responden berdasarkan indeks massa tubuh dapat dilihat pada diagram sebagai berikut:
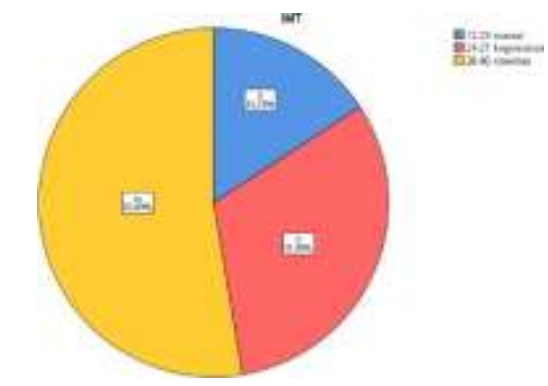

Diagram 4. Karakteristik Responden

Berdasarkan Indeks Massa Tubuh

(Data Primer, 2020)

Berdasarkan diagram diatas didapatkan hasil distribusi indeks massa tubuh responden dengan kategori normal pada skala nilai 17-23 sebanyak 3 orang $(15,79 \%)$, kategori kegemukan pada skala 24-27 sebanyak 6 orang $(31,58 \%)$, dan kategori obesitas dengan skala nilai lebih dari 28 sebanyak 10 orang $(52,63 \%)$. Dari hasil penelitian maka dapat disimpulkan bahwa salah satu faktor resiko ternyadinya osteoarthritis adalah obesitas. Sehingga nyeri yang ditimbulkan semakin terasa.

5. Penilaian Nyeri Lutut Sebelum Dan Sesudah Pemberian Progressive Resistance Exercise Dan Isometric Exercise

Nilai rata-rata nyeri lutut pre-test lebih tinggi dibandingkan nilai nyeri lutut post-test. Penurunan tersebut menunjukkan bahwa pemberian kombinasi progressive resistance exercise dan isometric exercise dapat menurunkan nyeri lutut yang dirasakan 
oleh responden pada penderita osteoarthritis.

Nilai rata-rata nyeri lutut pada penderita osteoarthritis sebagai berikut:

Tabel 1. Penilaian Nyeri Lutut Sebelum dan Sesudah Diberikan Progressive Resistance Exercise dan Isometric Exercise (Data Primer, 2020)

\begin{tabular}{cccc}
\hline Pengukuran & \multicolumn{3}{c}{ Nyeri Lutut } \\
Nyeri & Min & Max & Mean \\
\hline Pre-Test & 4 & 8 & 5,68 \\
Post-Test & 2 & 6 & 3,00 \\
\hline
\end{tabular}

6. Uji Normalitas

Uji normalitas yang digunakan pada penelitian ini adalah ShapiroWilk dengan hasil sebagai berikut:

Tabel 2. Uji Normalitas (Data Primer, 2020)

\begin{tabular}{lll}
\hline & Statistic & Sig \\
\hline Nyeri pre-test & .555 & .000 \\
Nyeri post-test & .507 & .000 \\
\hline
\end{tabular}

Berdasarkan hasil uji normalitas yang telah dilakukan menggunakan uji Shapiro-Wilk, didapatkan hasil bahwa data berdistribusi tidak normal karena nilai $p<0,005$. Karena distribusi data tidak normal maka selanjutnya uji hipotesis menggunakan Wilcoxon Test.

7. Uji Hipotesa

Pada penelitian ini uji hipotesa menggunakan uji Wilcoxon, dengan hasil sebagai berikut:

Tabel 3. Uji Hipotesa (Data Primer, 2020)

\begin{tabular}{|c|c|c|}
\hline & & $\begin{array}{l}\text { Nyeri Sebelum } \\
\text { Nyeri Sesudah }\end{array}$ \\
\hline Z & & $-4.264^{\mathrm{b}}$ \\
\hline $\begin{array}{l}\text { Asymp. } \\
\text { (2-tailed) }\end{array}$ & Sig. & .000 \\
\hline
\end{tabular}

Berdasarkan hasil uji wilcoxon diatas menunjukkan nilai $p<0,05$ maka dapat disimpulkan bahwa ada pengaruh kombinasi pemberian progressive resistance exercise dan isometric exercise terhadap penurunan nyeri lutut pada kasus osteoarthritis yang diberikan pada lansia RW 02 Kelurahan Triwung Lor.

\section{PEMBAHASAN}

Proses penuaan menjadi penyebab peningkatan kelemahan di sekitar sendi, penurunan kelenturan sendi, kalsifikasi tulang rawan dan menurunkan fungsi kondrosit sehingga mendukung terjadinya cidera pada lutut dan osteoarthritis (Gustina, 2020). Menurut Felson dan Zahang (2000) dalam Anggraini (2014), cidera pada sendi lutut diakibatkan oleh kegagalan mekanisme perlindungan sendi yang dipengaruhi oleh kapsul dan ligamen sendi, otot-otot, saraf sensori aferen dan tulang di dasarnya. Untuk mengurangi gesekan antar tulang, dibutuhkan cairan sendi (sinovial) sehingga dapat juga mencegah keletihan kartilago akibat terjadinya gesekan. Terdapat protein pada sendi (lubricin) yang berfungsi sebagai pelumas, namun apabila terdapat cidera protein ini akan berhenti disekresi. Kontraksi otot yag terjadi pada saat pergerakan sendi memberikan dampak pengurangan kecepatan (deselerasi) sebelum terjadinya tekanan pada tulang. Tulang di balik kartilago berfungsi untuk menyerap tekanan pada sendi. Kartilago dilumasi oleh cairan sendi yang mampu mengurangi gesekan antar tulang ketika bergerak. Penambahan usia seseorang akan berdampak dengan pengurangan kartilago sehingga timbulnya osteoarthritis lutut semakin besar. Kartilago yang berkurang menyebabkan gesekan pada tulang semakin terasa dan menimbulkan rasa nyeri.

$$
\text { Menurut Khairani (2013) }
$$

perempuan yang memasuki masa menopause akan mengalami penurunan hormon terutama estrogen dan fungsi fisiologis tubuh lainnya. Salah satu fungsi hormon estrogen yaitu membantu produksi kondrosit dalam matriks tulang, apabila estrogen menurun maka produksi 
kondrosit juga menurun. Hal tersebut akan mempengaruhi sintesa proteoglikan yang juga akan menurun sedangkan aktifitas lisosom meningkat. Pada wanita post menopouse terjadi penurunan kadar esterogen, sehingga meningkatkan sintesis sitokin seperti IL- 1, IL-6, TNF- $\alpha$ dan akan mempercepat terjadinya degradasi kolagen serta menghambat sintesis proteoglikan yang berpengaruh terhadap kesehatan sendi (Price, 2012).

Studi lain yang dilakukan oleh Misnadiarly tahun 2010 menyebutkan bahwa perempuan memiliki panggul yang lebih lebar dibandingkan laki-laki. Akibat panggul yang lebih lebar, menyebabkan kaki lebih merapat kebagian knee sehingga tekanan pada knee tidak merata. Massa otot disekitar knee perempuan juga lebih sedikit dibandingkan laki-laki.

Ibu rumah tangga dapat memicu terjadinya osteoarthritis karena disebabkan oleh aktivitas fisik yang membebani lutut dalam jangka waktu lama. Aktivitas fisik yang memicu terjadinya osteoarthritis misalnya mencuci piring, menyapu halaman rumah, mengepel lantai, naik turun tangga dan sebagainya. Beberapa faktor pekerjaan yang menimbulkan gerakan cepat dan terus menerus dengan beban yang berat pada rawan sendi seperti pekerjaan jongkok berdiri secara cepat dan terus menerus, mengangkat barang lebih $10 \%$ dari berat badan setiap hari juga berisiko osteoarthritis (Ilyas,2002 dalam Nursyarifah, dkk 2011).

$$
\text { Maharani (2007, dalam }
$$

Gumangsari, 2017) menyebutkan prevalensi penderita knee osteoarthritis lebih besar pada pekerja kuli pelabuhan, petani, penambang dibanding pekerja administrasi. Setiap penambahan berat, beban pada lutut juga akan meningkat sebesar 1-11/2 kg. Penambahan $1 \mathrm{~kg}$ akan meningkatkan risiko terjadinya osteoarthritis sebesar 10\%. Tulang rawan sendi lutut yang menerima beban yang berlebihan secara terus-menerus menyebabkan degenerasi meniskal dan robekan yang memicu perubahan ada tulang rawan sendi lutut. Bekerja dengan beban rata-rata $24,2 \mathrm{~kg}$, lama kerja yang lebih dari 10 tahun cenderung memiliki faktor risiko mengalami osteoarthritis lutut.

Menurut Felson D.T (2000) dalam Triyanti (2016) obesitas merupakan faktor terkuat dalam terjadinya osteoarthritis. Hal tersebut dikarenakan pada saat berjalan, setengah berat badan bertumpu pada sendi lutut. Peningkatan berat badan akan melipat gandakan beban sendi lutut saat berjalan dan menjadi penyebab terjadinya osteoarthritis. Studi pada Chingford menunjukkan bahwa setiap peningkatan Indeks Massa Tubuh (IMT) sebesar 2 unit (kira-kira $5 \mathrm{~kg}$ berat badan) akan berdampak pada peningkatan osteoarthritis lutus secara radiografik.

Studi lain yang dilakukan oleh Pratiwi pada tahun 2007 (dalam Gustina 2020) menyebutkan bahwa bahwa risiko obesitas untuk terkena osteoarthritis knee lebih besar sekitar 5-12 kali. Selain itu pada penderita osteoarthritis knee dengan obesitas akan mengalami peningkatan rasa nyeri yang lebih pada persendian lutut dibandingkan dengan pasien yang tidak obesitas.

Progressive Resistance Exercise yaitu sebuah latihan dinamis ritmik yang menggunakan beban dan secara bertahap ditingkatkan sesuai kemampuan kekuatan otot (Latifah, 2019). Progressive Resistance Exercise memberikan efek fisiologis berupa peningkatan aliran darah ke otot yang dituju karena kebutuhan oksigen juga bertambah, transportasi nutrisi ke otot bertambah, terjadi perubahan sistem sehingga terjadi peningkatan serabut otot lurik, penambahan jumlah protein dalam serabut otot, dan kenaikan jumlah motor unit sesudah diberikannya latihan. Apabila latihan diberikan secara rutin, akan mempengaruhi perubahan kekuatan otot. Perubahan tersebut akibat meningkatnya kerja sama antar grup otot yang berbeda, dan dapat terjadi 2-3 minggu setelah rutin latihan. Terdapat 
tiga enzim kompleks yang terlibat dalam perubahan adaptasi tersebut diantaranya adalah lypolisis kompleks, glycolisis kompleks, dan phoshecreatine ATP kompleks. Adaptasi ini berhubungan dengan sistem energi yang telah digunakan selama latihan (Pranatha, 2013).

Latihan berikutnya yaitu Isometric Exercise yang diberikan selama empat minggu dengan frekuensi dua kali dalam seminggu. Dalam penelitian Lasara pada tahun 2018, direkomendasikan latihan peregangan otot sebaiknya dilakukan selama dua sampai tiga kali seminggu. Hal tersebut dikarenakan dapat mendorong pelepasan hormon endorphine dan apabila dilakukan secara teratur, dapat mempengaruhi kesehatan penderita osteoarthritis. Menurut Tamsuri (2007, dalam Laasara 2018) nyeri sendi pada penderita osteoarthritis termasuk nyeri somatic dimana reseptor terletak pada otot dan tulang penyokong tubuh. Endorphine merupakan salah satu neuromodulator pada tubuh yang dapat menghambat impuls nyeri.

Peningkatan intensitas latihan juga akan berdampak pada hormon epinefrin. Hormon epinefrin dapat mengaktifkan reseptor $\alpha$ dan $\beta$ sehingga berpengaruh terhadap peningkatan glikolisis, relaksasi otot polos pembuluh darah, stimulasi lipolisis kontraksi miokardium, peningkatan laju darah, peningkatan glikolisis otot yang menyebabkan peningkatan kekuatan dan berakibat pada peningkatan aliran darah. Dengan adanya peningkatan aliran darah, kerusakan jaringan dapat dihambat (Guyton, 2012 dalam Yuliadarwati, dkk., 2016).

Growth hormone bekerjasama dengan cytokine dalam proses inflamasi. Saat terjadi cidera atau pembedahan secara vaskuler, kalsium intraseluler dikeluarkan dan mengaktivasi fakor VII dan proses koagulasi ekstrinsik. Saat bersamaan terjadi reflek vasokontriksi untuk membantu hemostatis yang bekerja menjaga hasil dari koagulasi berupa pluq fibrin. Pembentukan pembekuan fibrin akan mengaktifkan mekanisme lain dari bagian tubuh berupa fibrolisis yang melisiskan bekuan fibrin.

Proses ini untuk mencegah bekuan fibrin sehingga memudahkan migrasi sel ke dalam area luka dan memulai fase penyembuhan selanjutnya (Deodhar \& Rana, 1997 dalam Yuliadarwati,dkk., 2016). Teori respirasi menjelaskan bahwa udara dari luar yang mengandung oksigen $\left(\mathrm{O}_{2}\right)$ kedalam tubuh serta menghembuskan udara yang banyak mengandung karbondioksida $\left(\mathrm{CO}_{2}\right)$ sebagai sisa dari oksidasi keluar dari tubuh. Sisa respirasi berperan untuk menukar udara ke permukaan dalam paru-paru. Spinal cord dan sel-sel reseptor yang menerima stimulasi nyeri periferal dihambat oleh stimulasi nyeri periferal dihambat oleh stimulasi dari serabut-serabut saraf yang lain. Stimulasi yang menyenangkan dari luar dapat merangsang sekresi endorfin, sehingga stimulasi nyeri yang dirasakan menjadi berkurang (Priharjo, 2013 dalam Yuliadarwati., 2016).

Berdasarkan kesimpulan diatas alasan penelitian ini menggunakan kombinasi progressive resistance exercise dan isometric exercise karena pemberian progressive resistance exercise pada penderita osteoarthritis dapat meningkatkan kekuatan otot secara signifikan, peningkatan serabut otot lurik, dan kenaikan jumlah motor unit (Latifah, 2019). Dengan peningkatan kekuatan otot diharapkan dapat menstabilkan sendi pada posisi yang tepat dan menghindari tekanan yang dapat menyebabkan nyeri. Gerakan yang berulang dan teratur dapat meningkatkan aliran darah sehingga metabolisme meningkat dan terjadi peningkatan difusi cairan melalui matriks tulang. Adanya kontraksi otot yang kuat akan mempermudah mekanisme pumping action (memompa cairan untuk bersitkulasi) sehingga proses metabolisme 
dan sirkulasi lokal dapat berlangsung dengan baik karena vasodilatasi dan relaksasi setelah kontraksi maksimal dari otot. Maka dari itu pengangkutan sisa-sisa metabolisme dan asetabolic yang diproduksi melalui proses inflamasi dapat berjalan lancar dan rasa nyeri dapat berkurang (Pramudaningsih, 2017).

\section{KESIMPULAN}

Penelitian ini dapat diambil kesimpulan bahwa Pemberian Kombinasi Progressive Resistance Exercise dan Isometric Exercise dinilai efektif dalam menurunkan nyeri pada penderita osteoarthritis.

\section{REFERENCES}

Anggraini, N. E., \& Hendrati, L. Y. (2014). Hubungan Obesitas dan Faktor-Faktor Pada Individu dengan Kejadian Osteoarthritis Genu The Relation of Obesity and Individual Factors with Knee Osteoarthritis. Jurnal Berkala Epidemiologi.

Cahyaningtyas, P. Y., Abi Muhlisin, S. K. M., \& Arum Pratiwi, S. K. (2019). Gambaran Pengetahuan Keluarga Tentang Cara Penanganan Radang Sendi (Osteoarthritis) Di Komunitas (Doctoral dissertation, Universitas Muhammadiyah Surakarta)

Gustina, E. (2020). Faktor - Faktor Yang Mempengaruhi Osteoartritis Studi Kasus Kontrol Di Rumah Sakit TK II Putri Hijau Medan Tahun 2017. EXCELLENT MIDWIFERY JOURNAL.

Khairani, Y. (2013). Hubungan Umur, Jenis Kelamin, IMT, dan Aktivitas Fisik dengan Kejadian Osteoathritis Lutut. Jambi Medical Journal.

Kisner, C., \& Colby, L. A. (2012). Therapeutic Exercise Foundations and Techniques, Sixth Edition, F.A. Davis Company, America.

Laasara, N. (2018). Pengaruh Latihan Isometric Quadriceps Terhadap Penurunan Skala Nyeri \& Kekakuan Sendi Lutut Pada Klienosteoarthritis
Lutut Di Wilayah Puskesmas Gamping Ii Sleman Yogyakarta. Dinamika Kesehatan.

Latifah, N. (2019). Pengaruh Penambahan Progressive Resistance. 14. http://digilib.unisayogya.ac.id/id/epri nt/ 4672

Made, G. G. N. (2017). Hubungan Gaya Hidup Dengan Osteoarthritis Lanjut Usia Wanita di Puskesmas Cakranegara Kota Mataram 2016. Hubungan Gaya Hidup Dengan Osteoarthritis Lanjut Usia Wanita Di Puskesmas Cakranegara Kota Mataram 2016.

Misnadiarly. 2010. Osteoartritis : Penyakit Sendi pada Orang Dewasa dan Anak. Jakarta: Pustaka Popouler Obor.

Nursyarifah, R. S., Herlambang, K. S., \& A, M. T. (2013). Hubungan Antara Obesitas dengan Osteoartritis Lutut di RSUP Dr . Kariadi Semarang Periode Oktober- Desember 2011. Jurnal Kedokteran Muhammadiyah.

Pramudaningsih, Rahmawatidevi (2017). Pengaruh Strengthening Exercise Terhadap Penurunan Intensitas Nyeri Lutut Pada Penderita Osteoarthritis. Jurnal Profesi Keperawatan Akademi Keperawatan Krida Husada Kudus, 4(2).

Pranatha, I. Nyoman, A. (2013). Penambahan Latihan Penguatan Dengan EN TREE Pada Intervensi Ultrasound Dan TENS Untuk Mengurangi Nyeri Pada Penderita Osteoarthritis Lutut Di RSUP Sanglah Denpasar (Doctoral Disertatio, Universitas Udayana).

Price, A., \& Wilson, M. (2012). Patofisiologi Konsep Klinis Prosesproses Penyakit Edisi 6 Vol 2. In Jakarta.

Richmond, J., Hunter, D., Irrgang, J., Jones, M. H., Snyder-Mackler, L., dkk. (2010). American academy of orthopaedic surgeons clinical 
practice guideline on the treatment of osteoarthritis (OA) of the knee. In Journal of Bone and Joint Surgery Series

https://doi.org/10.2106/JBJS.I.00982

Triyanti Purnamasari, N. I. M. (2016).

Hubungan Antara Usia, Jenis

Kelamin, Aktivitas Fisik Dan

Obesitas Dengan Kejadian

Osteoarthritis Lutut Di Rumah Sakit

Muhammadiyah Palembang

(Doctoral Dissertation, Universitas

Muhammadiyah Palembang).

Vincent, K. R., Montero, C., \& Vincent, H. K. (2013). Progressive enhanced eccentric or concentric resistance exercise training for knee osteoarthritis. Osteoarthritis and Cartilage.

https://doi.org/10.1016/j.joca.2013.0 2.577

Yuliadarwati, N. M., Sari, G. M., \& Wardani, T. (2016). Pengaruh Muscle Energy Tehnique Terhadap Penurunan Intensitas Nyeri Pada Ibu Pascaseksio Sesaria. Jurnal Penelitian Kesehatan, 4(1), 14-19.

Zhang, Y., \& Jordan, J. M. (2010). Epidemiology of osteoarthritis. In Clinics in Geriatric Medicine.

https://doi.org/10.1016/j.cger.2010.0 $\underline{3.0} \underline{01}$ 